\title{
In-situ Product Recovery as a Strategy to Increase Product Yield and Mitigate Product Toxicity
}

\author{
Yuen Ling Ng* and Yi Yang Kuek \\ Department of Chemical and Environmental Engineering, University of Nottingham, University Park, Nottingham NG7 \\ 2RD, United Kingdom
}

\begin{abstract}
Product inhibition is often the cause limiting the maximum product concentration attainable in fermentation. This study showed the product yield of $p$-cresol could be improved by in-situ product recovery (ISPR). Escherichia coli transformed with the hpd BCA operon from Clostridium difficile was shown in this study to express $p$ hydroxyphenylacetate decarboxylase which converted $p$-hydroxyphenylacetate into $p$-cresol under anaerobic fermentation. Toxicity of $p$-cresol found at a concentration as low as $5 \mathrm{mM}$ in a broth spiked with $p$-cresol was shown to have limited the maximum product concentration at $1 \pm 0.1 \mathrm{mM}$ after 30 hours of batch fermentation. Product yield was however shown to increase by $51 \%$ when activated carbon was used to remove $p$-cresol in-situ production. The activated carbon concentrated $p$-cresol on the solid adsorbent which was subsequently separated by sedimentation and $p$-cresol recovered by ultrasonic-assisted solvent extraction. Desorption of $p$-cresol from the spent activated carbon allowed the adsorbent to be regenerated for further product recovery. The ISPR strategy reported here was shown to improve the yield of a toxic product, was sustainable, and when adapted to a continuous process would increase productivity.
\end{abstract}

Keywords: adsorption, Escherichia coli, glycyl radical enzyme, in-situ product recovery, p-cresol, product toxicity.

\section{INTRODUCTION}

Para-cresol ( $p$-cresol) is an important intermediate for the production of antioxidants in food, personal care products, pharmaceuticals, materials, fuels, oils, herbicides, flavours, fragrances, dyes, resins, disinfectants and preservatives. Production of $p$-cresol by Clostridium difficile (C. difficile) was via the expression of the hpd BCA operon encoding the highly oxygen-sensitive Glycyl Radical Enzyme (GRE) $p$-hydroxyphenylacetate decarboxylase [1]. Although C. difficile was able to produce $p$-cresol, it cannot be used in large-scale production due to its virulence in causing lifethreatening gastrointestinal infection in humans $[2,3]$. This study therefore explored the possibilities of producing $p$ cresol by genetically modifying the Generally Recognised As Safe (GRAS) host Escherichia coli (E. coli) to express $p$ hydroxyphenylacetate decarboxylase, and to convert $p$ hydroxyphenylacetate (HPA) into $p$-cresol. The hpd BCA operon from $C$. difficile was cloned into plasmids which were then used to transform $E$. coli to produce $p$-cresol in whole-cell fermentation. Since E. coli was a facultative anaerobe and was most commonly used in recombinant DNA technology [4], it was postulated that the expression as well as the enzymatic activity of the GRE would be possible during anaerobic fermentation.

$P$-cresol was reported to be toxic to cells whereby the maximum concentration tolerable by $C$. difficile was

*Address correspondence to this author at the Department of Chemical and Environmental Engineering, University of Nottingham, University Park, Nottingham NG7 2RD, United Kingdom; Tel: +44(0)115 951 3770;

Fax: +44(0)115951 4115; E-mail: yuen.ng@nottingham.ac.uk reported at $35 \mathrm{mM}$ [5]. It was this toxicity that attributed $C$. difficile its virulent characteristics [6], and rendered the bacteria a competitive advantage over other microorganisms in its natural habitat [7]. This study explored the possibilities of mitigating the toxicity imposed by $p$-cresol by implementing an ISPR strategy in order to improve product yield and productivity. The model with $p$-cresol would allow adaptation to other bioproducts, thus providing solutions to product inhibition and improve product yield [8-12].

Solvent extraction using a biphasic extraction system was reported in [13] for product recovery. [14] and [15] suggested the requirement for extraction solvents to have $\log \mathrm{P}$ values of at least 4 in order to ensure biocompatibility and non-toxicity to the cells during product separation. Alkanes containing 7 carbons and above [16, 17], oleyl alcohol [18], dibutyl phthalate [19, 20] and ethyl laurate [21] were some common organic solvents used for product recovery. Although solvent extraction could be used for product separation, possible formation of emulsion during the product recovery step could result in subsequent difficulty in a clean phase separation. High energy consumption required in the final product purification step due to the high boiling points of extraction solvents, and the reported decrease in the growth rates of cells exposed to toxic solvents [17] rendered solvent extraction to be a non-ideal product separation and purification method.

[22] suggested adsorption to be a more viable separation method for biological products where polymeric resins were reported by [23] to be used for the ISPR of second-generation biofuels. Adsorption of $p$-cresol by different types of adsorbents in the applications of hemodialysis, wastewater 
treatment and as first-principle adsorption study was reported by various authors in Table 1.

This study explored the feasibility of using activated carbon (AC) adsorption for the separation and recovery of $p$ - cresol from fermentation broth which was subsequently recovered by solvent extraction. The decoupling of the solvent extraction process from fermentation via adsorption allowed the flexibility of using an extraction solvent with a lower

Table 1. Adsorption of $p$-cresol by Various Types of Adsorbents

\begin{tabular}{|c|c|c|c|}
\hline Adsorbent & Adsorption characteristics & Application & Reference \\
\hline High silica MFI zeolite & $\begin{array}{l}\text { The adsorbent was able to remove } 80-85 \% \\
\text { of } p \text {-cresol from solution, although the re- } \\
\text { moval performance was reduced in the pres- } \\
\text { ence of serum. }\end{array}$ & Hemodialysis & [24] \\
\hline $\begin{array}{l}\text { Hypercross-linked polymer, bituminous coal } \\
\text { activated carbon, phartenium-based activated } \\
\text { carbon, fly ash, clay and silicalite }\end{array}$ & $\begin{array}{l}\text { Maximum adsorption capacity was achieved } \\
\text { with the hypercross-linked polymer at } 1.8 \\
\mathrm{mmol} / \mathrm{g} \text { of polymer. }\end{array}$ & Adsorption of $p$-cresol from water. & [25] \\
\hline $\begin{array}{l}\text { Polyaniline-modified mesoporous carbon } \\
\text { (CMK-1/PANI) }\end{array}$ & $\begin{array}{l}\text { Maximum adsorption capacity for } p \text {-cresol } \\
\text { was } 1.5 \mathrm{mmol} / \mathrm{g} \text { of adsorbent. Acidic- } \\
\text { alkaline interaction between the amine } \\
\text { groups on the surface of the adsorbent and } \\
\text { the phenolic compounds was hypothesised to } \\
\text { have improved the performance of the ad- } \\
\text { sorbent. }\end{array}$ & $\begin{array}{l}\text { Adsorption of phenolic compounds includ- } \\
\text { ing } p \text {-cresol from aqueous solutions. }\end{array}$ & [26] \\
\hline $\begin{array}{l}\text { Crosslinked zinc chloride, chloromethylated } \\
\text { poly(styrene-co-divinylbenzene) resin (HJ- } \\
\text { 1), and Amberlite XAD-4 resin }\end{array}$ & $\begin{array}{l}\text { Adsorption capacities of } p \text {-cresol were re- } \\
\text { ported at } 1.3 \mathrm{mmol} / \mathrm{g} \text { of } \mathrm{HJ}-1 \text {, and } 0.6 \\
\mathrm{mmol} / \mathrm{g} \text { of Amberlite XAD- } 4 \text {. }\end{array}$ & $\begin{array}{l}\text { Adsorption of } p \text {-cresol from aqueous solu- } \\
\text { tions at } 25 \text { to } 40{ }^{\circ} \mathrm{C} \text {. }\end{array}$ & [27] \\
\hline $\begin{array}{l}\text { Amberlite XAD- } 4 \text { and NDA polymeric } \\
\text { adsorbents }\end{array}$ & $\begin{array}{l}\text { Maximum adsorbate concentration was at } \\
1.8 \mathrm{mmol} / \mathrm{g} \text { of adsorbent. The basic func- } \\
\text { tional groups and oxygen groups on the } \\
\text { surface of NDA- } 99 \text { were reported to enhance } \\
\text { adsorption. }\end{array}$ & $\begin{array}{l}\text { Adsorption study with different types of } \\
\text { adsorbents. }\end{array}$ & [28] \\
\hline Fly ash made from wood & $\begin{array}{l}\text { Adsorption capacity for } p \text {-cresol was at } 0.49 \\
\mathrm{mmol} / \mathrm{g} \text { of adsorbent. }\end{array}$ & $\begin{array}{l}\text { The application of low-cost adsorbents for } \\
\text { the removal of phenolic compounds from } \\
\text { wastewater. }\end{array}$ & [29] \\
\hline $\begin{array}{l}\text { Sulphuric acid-treated parthenium-based } \\
\text { activated carbon }\end{array}$ & $\begin{array}{l}\text { Optimum adsorption capacity of } p \text {-cresol } \\
\text { was reported at } 0.56 \mathrm{mmol} / \mathrm{g} \text { of parthenium- } \\
\text { based activated carbon, compared to } 0.78 \\
\text { mmol/g of commercial activated carbon. }\end{array}$ & $\begin{array}{l}\text { Adsorption of } p \text {-cresol from aqueous solu- } \\
\text { tions at } \mathrm{pH} 6 \text {. Maximum concentration of } \\
p \text {-cresol used in solution was } 1000 \mathrm{mg} / \mathrm{L} \text {. }\end{array}$ & [30] \\
\hline $\begin{array}{l}\text { Cellulose diacetate and triacetate mem- } \\
\text { branes, synthetic polyamide, polysulfone, } \\
\text { polyacrylonitrile, polymethylmethacrylate, } \\
\text { zeolite and silicalite }\end{array}$ & $\begin{array}{l}\text { Adsorption performance of silicalite adsorb- } \\
\text { ent was the best, where a 2-min equilibration } \\
\text { time was adequate for the adsorbate uptake. } \\
\text { The maximum adsorption capacity was } 0.98 \\
\text { mmol/g of silicalite. }\end{array}$ & Hemodialysis & [31] \\
\hline Spectracarb activated carbon cloth & $\begin{array}{l}\text { Adsorption capacities of } p \text {-cresol were } 1.9 \\
\mathrm{mmol} / \mathrm{g} \text { of activated carbon in water, } 1.7 \\
\mathrm{mmol} / \mathrm{g} \text { of activated carbon in sulphuric acid } \\
\text { solution, and } 0.65 \mathrm{mmol} / \mathrm{g} \text { of activated car- } \\
\text { bon in sodium hydroxide solution. }\end{array}$ & $\begin{array}{l}\text { Adsorption of } p \text {-cresol at } 30^{\circ} \mathrm{C} \text { in water, in } \\
1 \mathrm{M} \text { sulphuric acid and in } 0.1 \mathrm{M} \text { sodium } \\
\text { hydroxide solution. }\end{array}$ & [32] \\
\hline Adsorbents prepared from fertiliser waste & $\begin{array}{l}\text { Adsorption capacity of } p \text {-cresol was } 0.38 \\
\mathrm{mmol} / \mathrm{g} \text { of fertiliser waste adsorbent, com- } \\
\text { pared to } 0.85 \mathrm{mmol} / \mathrm{g} \text { of commercial acti- } \\
\text { vated charcoal. }\end{array}$ & Adsorption of $p$-cresol in water. & [33] \\
\hline $\begin{array}{l}\text { Amberlite XAD- } 4 \text { and chloromethylated } \\
\text { styrene-divinylbenzene copolymer beads } \\
(\mathrm{NJ}-8) \text {. }\end{array}$ & $\begin{array}{l}\text { Adsorption capacities of } p \text {-cresol were } 2.5 \\
\mathrm{mmol} / \mathrm{g} \text { of } \mathrm{NJ}-8 \text { and } 1.2 \mathrm{mmol} / \mathrm{g} \text { of XAD- } 4 \text {. }\end{array}$ & Adsorption of $p$-cresol in water. & [34] \\
\hline
\end{tabular}


boiling point to separate and recover the product, thus enabling energy savings in subsequent product purification processes. Desorption of $p$-cresol from the spent adsorbent allowed the recovery and reuse of the adsorbent for further product separation and recovery. This study was divided into various phases in order to establish the toxicity levels of $p$ cresol on E. coli, to test and establish whether the productivity and yield of $p$-cresol could be improved by ISPR, and to determine the suitability and capacity of the integrated adsorption-cum-solvent extraction ISPR strategy in the recovery of $p$-cresol.

\section{MATERIALS AND METHODS}

\subsection{Cloning}

Genomic DNA was extracted from C. difficile $630 \Delta \mathrm{erm}$ as described in $[35,36]$. The DNA was PCR-amplified, cloned into the modular vectors pMTL84151 and pMTL84251, and were then used to transform Top10 E. coli. The transformed cells were cultured aerobically from where the positive clones with chloramphenicol (CM) and erythromycin (EM) resistance were screened and isolated. The clones were maintained aerobically and were switched to anaerobic fermentation for the production of $p$-cresol.

\subsection{Production of $p$-cresol Using Transformed $E$. coli Cells}

Both $\mathrm{CM}$ and EM clones were maintained on Terrific Broth (TB) media containing $12 \mathrm{~g} / \mathrm{L}$ Bacto-Tryptone, $24 \mathrm{~g} / \mathrm{L}$ yeast extract, $4 \mathrm{ml} / \mathrm{L}$ glycerol, $2 \mathrm{ml} / \mathrm{L}$ Vishniac trace element solution, $20 \mathrm{ml} / \mathrm{L} \mathrm{FeSO}$, $4 \mathrm{~g} / \mathrm{L} \mathrm{K}_{2} \mathrm{HPO}_{4}$ and $2 \mathrm{~g} / \mathrm{L} \mathrm{KH}_{2} \mathrm{PO}_{4}$. The selective media was supplemented with either chloramphenicol at a concentration of $12.5 \mu \mathrm{g} / \mathrm{ml}$, or erythromycin at a concentration of $500 \mu \mathrm{g} / \mathrm{ml}$, for the CM and EM clones respectively. The Vishniac trace element solution was made up of $0.1 \mathrm{~g} / \mathrm{L}$ EDTA-disodium salt, $2.2 \mathrm{~g} / \mathrm{L} \mathrm{ZnSO}_{4}, 5.54 \mathrm{~g} / \mathrm{L}$ $\mathrm{CaCl}_{2}, 5.06 \mathrm{~g} / \mathrm{L} \mathrm{MnCl}_{2} \cdot 4 \mathrm{H}_{2} \mathrm{O}, 5 \mathrm{~g} / \mathrm{L} \mathrm{FeSO}_{4} \cdot 7 \mathrm{H}_{2} \mathrm{O}, 1.1 \mathrm{~g} / \mathrm{L}$ $\left(\mathrm{NH}_{4}\right) .6 \mathrm{Mo}_{7} \mathrm{O}_{24} .4 \mathrm{H}_{2} \mathrm{O}, 1.57 \mathrm{~g} / \mathrm{L} \mathrm{CuSO}_{4} .5 \mathrm{H}_{2} \mathrm{O}$, and $1.61 \mathrm{~g} / \mathrm{L}$ $\mathrm{CoCl}_{2} \cdot 6 \mathrm{H}_{2} \mathrm{O}$. The trace element solution was adjusted to $\mathrm{pH}$ 6 with $\mathrm{KOH}$ and stored at $4{ }^{\circ} \mathrm{C}$ until the solution was used. The cell stocks were frozen down in the same culture media formulation with the addition of $100 \mathrm{ml} / \mathrm{L}$ glycerol for cryopreservation.

The cells were maintained at $37{ }^{\circ} \mathrm{C}$ on agar plates and were cultured in liquid broth for the production of $p$-cresol. $100 \mathrm{mM}$ of $p$-hydroxyphenylacetic acid stock solution was neutralised to $\mathrm{pH} 7$ with $10 \mathrm{M}$ of sodium hydroxide solution before it was used as a substrate for the production of $p$ cresol. The neutralised sodium $p$-hydroxyphenylacetate (HPA) stock solution was added to $20 \mathrm{ml}$ of liquid culture media to the required final concentrations for the respective experiments. The culture medium and substrates were autoclaved and placed in the Don Whitley anaerobic workstation while hot. The solutions were left in the anaerobic workstation overnight for equilibration prior to inoculation the next day. Cells that were cultured to the mid-exponential growth phase in liquid culture media were used to inoculate the fermentation broth at $10 \%$ (volume by volume) $(\mathrm{v} / \mathrm{v})$. The culture universal bottles were capped and taped down with parafilm for anaerobic fermentation at $37^{\circ} \mathrm{C}$ and 200 rpm. Samples were taken at regular intervals to determine culture growth, product formation and substrate consumption.

\subsection{Analytical Methods}

Culture growth was quantified by optical density (OD) measurement at $600 \mathrm{~nm}$ using the UV Mini 1240 Shimadzu $\mathrm{UV}$-Vis Spectrometer. Colony forming units (CFU) were used to determine culture growth when $\mathrm{AC}$ was used in the experiments in order to avoid interference in the OD measurement caused by fines generated from the AC during agitation. CFU was determined by diluting the cell sample and spreading on agar plates. The agar plates were incubated at $37{ }^{\circ} \mathrm{C}$ overnight and the number of colonies was counted. The values of $\mathrm{CFU} / \mathrm{ml}$ were then calculated, taking into account the dilution factors used in the experiments.

The concentrations of $p$-cresol and HPA were quantified using the High Performance Liquid Chromatography (HPLC) (Agilent 1200 HPLC) with an Agilent Eclipse XDBC18 column, a detector at $270 \mathrm{~nm}$, and a temperature controller at $25{ }^{\circ} \mathrm{C}$. The mobile phase containing $70 \%(\mathrm{v} / \mathrm{v})$ acetonitrile, $30 \%(\mathrm{v} / \mathrm{v})$ water and $0.5 \%(\mathrm{v} / \mathrm{v})$ acetic acid was used at $0.4 \mathrm{ml} / \mathrm{min}$. The samples were taken from the fermentation broth and were centrifuged repeatedly at $6000 \mathrm{rpm}$ for 10 min at $4{ }^{\circ} \mathrm{C}$ until no $\mathrm{AC}$ fines were left in the sample. $1 \mu l$ of the supernatant was injected into the HPLC for analysis. Samples that were not analysed immediately were frozen down to $-20{ }^{\circ} \mathrm{C}$ and were thawed prior to analysis. Internal standards containing $20 \mu \mathrm{g} / \mathrm{ml}$ of nitrobenzene were used in the sample analysis.

The production of $p$-cresol in the fermentation broth was confirmed by qualitative analysis using the Agilent 7890A Gas Chromatography (GC) coupled to the Agilent 5975C Mass Spectrometer Detector (MSD). A HP5MS column with a $\mathrm{N}_{2}$ mobile phase at $0.5 \mathrm{ml} / \mathrm{min}$ was used for the analyses. The GC program was set at $70{ }^{\circ} \mathrm{C}$ for $2 \mathrm{~min}$, followed by a $10{ }^{\circ} \mathrm{C} / \mathrm{min}$ ramp to $325{ }^{\circ} \mathrm{C}$, and was held at $325{ }^{\circ} \mathrm{C}$ for 10 $\mathrm{min}$. The samples were centrifuged at $6000 \mathrm{rpm}$ for $10 \mathrm{~min}$ at $4{ }^{\circ} \mathrm{C}$ from which $3 \mathrm{~mL}$ of the supernatant was acidified with $0.2 \mathrm{~mL}$ of $0.1 \mathrm{M} \mathrm{HCl}$. The acid-treated samples were extracted with an equal volume of dichloromethane and the organic phase was injected into the GC-MSD for analysis.

\subsection{Recovery of $p$-cresol from the Fermentation Broth Using Activated Carbon}

The AC used for the experiments were obtained from Sigma Aldrich. C3014 was wetted and equilibrated with deionised water at $1 \mathrm{~g}$ per $10 \mathrm{ml}$ of water in the Certomat BS-1 Sartorius orbital shaker at $200 \mathrm{rpm}$ and $37{ }^{\circ} \mathrm{C}$ for $24 \mathrm{~h}$ before autoclave. The sterilised $\mathrm{AC}$ was then neutralised to $\mathrm{pH} 7$ with sterile $0.1 \mathrm{M} \mathrm{HCl}$ before it was washed to remove fines. The AC was then coated with Dextran, based on a modification of the method described by [37]. The coating solution consisted of $0.25 \mathrm{M}$ sucrose, $1.5 \mathrm{mM} \mathrm{MgCl}_{2}, 10 \mathrm{mM}$ HEPES, and $0.05 \%$ (weight by volume) (w/v) Dextran T-70 obtained from Sigma Aldrich. The coating was performed at $180 \mathrm{rpm}$ and $30^{\circ} \mathrm{C}$ for 3 days before the $\mathrm{AC}$ was washed and used for experiments. 


\subsection{Desorption of p-cresol from the Activated Carbon Using Ultrasonic-assisted Solvent Extraction}

Solvent extraction was used to recover the $p$-cresol concentrated on the AC. Ethanol was selected as the extraction solvent based on its miscibility and good solubility with many chemicals including those containing the hydroxyl functional group. The extraction was performed batch wise with incremental volumes of $5 \mathrm{ml}$ of solvent for the first 4 cycles of extraction, followed by $20 \mathrm{ml}$ each for the subsequent 6 more cycles of extraction. The saturated $\mathrm{AC}$ was immersed with the extraction solvent in glass tubes, and was heated to $50{ }^{\circ} \mathrm{C}$ in the $\mathrm{U} 300 \mathrm{H}$ Ultra Wave Heated Ultrasonic Bath before sonication at $44 \mathrm{kHz}$ for $15 \mathrm{~min} .1 .2 \mathrm{ml}$ of sample was taken from the extraction solvent and was analysed for $p$-cresol using the HPLC. The \% cumulative recovery was calculated based on the amount of $p$-cresol extracted into the solvent with respect to the original amount of $p$ cresol pre-adsorbed on the AC.

\section{RESULTS AND DISCUSSION}

The hpd BCA operon was cloned from $C$. difficile and expressed in E. coli, where the expressed p-hydroxyphenylacetate decarboxylase was shown to convert HPA into $p$ cresol under anaerobic conditions (Fig. 1). The production of $p$-cresol was correlated with the depletion of HPA in the fermentation broth, and reached a maximum concentration of $1 \pm 0.1 \mathrm{mM}$ with the EM clone. The CM clone showed a lower product concentration compared to the EM clone, and hence it was not used in subsequent experiments. Toxicity of $p$-cresol was observed to take effect on the cells at $5 \mathrm{mM}$ of spiked $p$-cresol concentration as shown in Fig. (2). This toxicity was hypothesised to have caused the low maximum

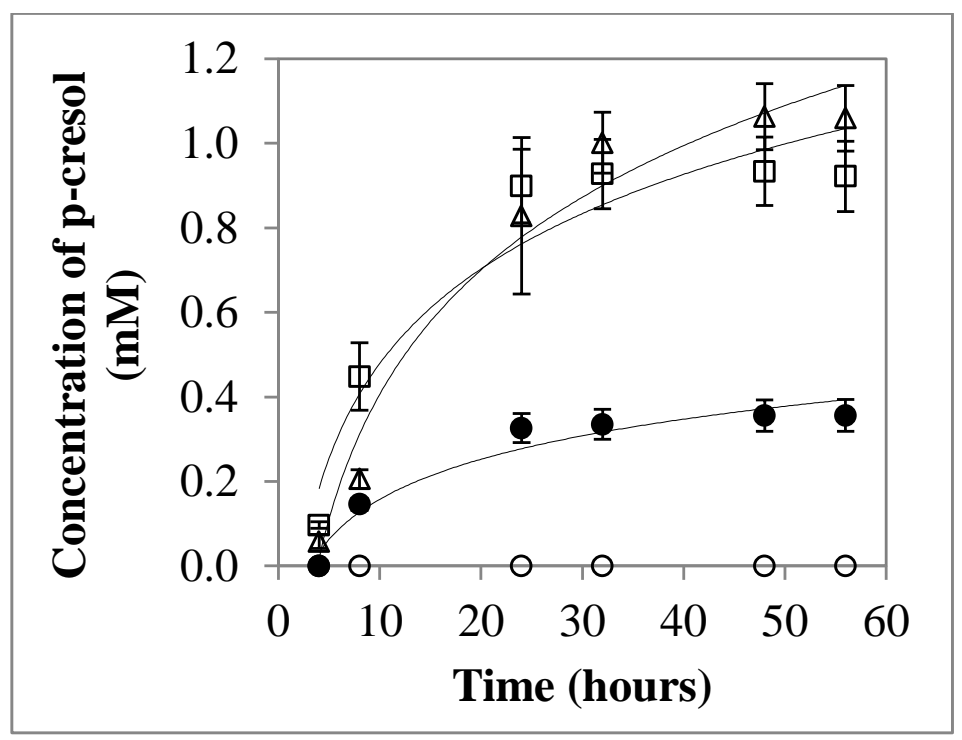

Fig. (1). Production of $p$-cresol by EM clone using various concentrations of HPA without AC. HPA was used at concentrations of: 0 mM $(\mathrm{O}), 10 \mathrm{mM}(\square), 50 \mathrm{mM}(\triangle)$ and $90 \mathrm{mM}(\bullet)$.

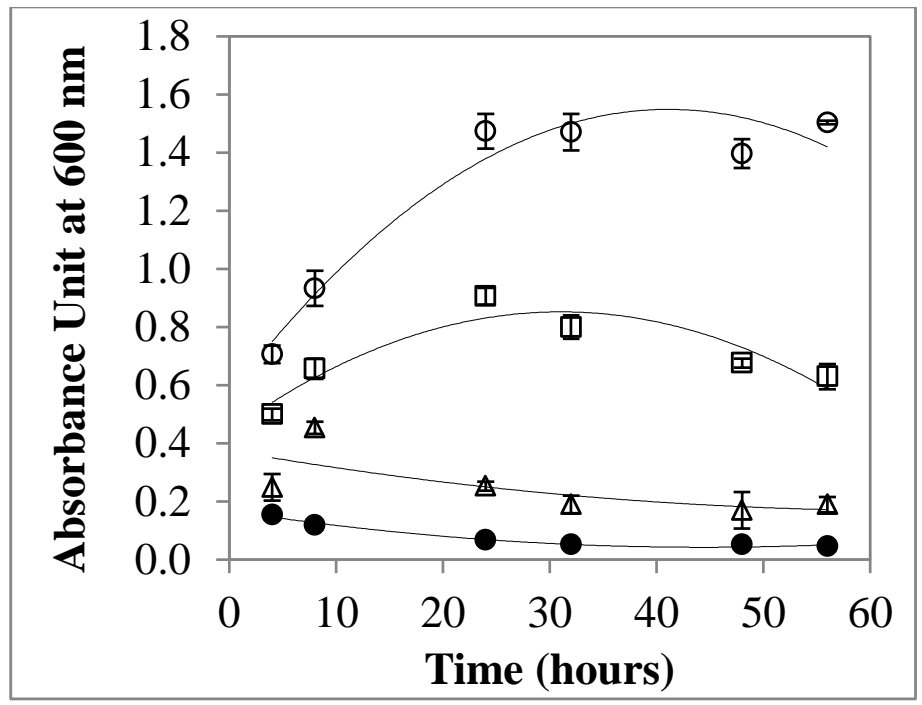

Fig. (2). Toxicity test of $p$-cresol on EM clone at various concentrations of $p$-cresol without HPA and without AC. $P$-cresol was used at concentrations of: $0 \mathrm{mM}(\mathrm{O}), 2 \mathrm{mM}(\square), 5 \mathrm{mM}(\triangle)$ and $10 \mathrm{mM}(\bullet)$. 
concentration of $p$-cresol attainable in the fermentation as shown in Fig. (1).

Granular AC was used in the ISPR strategy to explore the possibility of increasing the productivity of $p$-cresol by removing the accumulation of the toxic product from the fermentation broth. The AC used in these experiments was commercially supplied to treat aqueous solutions, with applications in serum purification to remove steroid hormones. Since the AC was supplied to treat serum, it was postulated to be suitable for microbial cell culture without causing poisoning to the cells. Dextran T-70 was used to coat the AC in order to prevent any possible competitive adsorption imposed by nutrients in the fermentation broth. Experiment was conducted to determine whether there was any effect attributed by the coating on the adsorption of $p$-cresol.

Batch wise adsorption was performed at various concentrations of $p$-cresol in order to determine the performance characteristics and the adsorption capacities. A 500-mM concentration of $p$-cresol was used in the adsorption study, notwithstanding this concentration was above its solubility limit. This was to ensure that the $\mathrm{AC}$ has reached saturation during the determination of the adsorption capacity. A 3phase mixture including a solid phase with 2 aqueous and organic phases was formed at the onset of the experiment with $500 \mathrm{mM}$ of $p$-cresol. The 3-phase mixture became a 2phase mixture as the adsorption progressed and as the $\mathrm{AC}$ adsorbed the $p$-cresol from the liquid phase. The adsorption of $p$-cresol by the $\mathrm{AC}$ was observed to be very rapid when 5 and $148 \mathrm{mM}$ of $p$-cresol were used respectively. All of the $p$ cresol in the initial $5 \mathrm{mM}$ concentration was taken up by the $\mathrm{AC}$ within the first $5 \mathrm{~h}$ of experiment. The adsorption capacities of both dextran-coated and non-coated AC were $2.6 \pm$ $0.088 \mathrm{mmol} / \mathrm{g}$ of $\mathrm{AC}$, where the Dextran coating showed negligible effect on the adsorption of $p$-cresol. The AC used in this study was shown to have comparable, if not higher, adsorption capacity compared to those of other adsorbents shown in Table 1.

Solvent extraction assisted with ultrasonication at low frequency was used to recover $p$-cresol from the AC. The strategy was to exploit the cleaning function of ultrasonica- tion to desorb $p$-cresol from the spent AC. Fig. (3) shows ethanol extraction of $p$-cresol with 10 batches of fresh extraction solvent. Extraction cycles 1 to 4 were done with 5 $\mathrm{ml}$ of ethanol each, while cycles 6 to 10 were done with 20 $\mathrm{ml}$ of the solvent each. $85 \%$ of the adsorbed $p$-cresol was shown to be recoverable into the extraction solvent at cycle 6 , with a total of $60 \mathrm{ml}$ of solvent used. It was hypothesised that strong interaction of $p$-cresol in the micro pores of the $\mathrm{AC}$ could have caused the remaining $15 \%$ of $p$-cresol to be non-desorbable.

Figs. (4 and 5) show the culture growth curve and the $p$ cresol production curve respectively for the EM clone. The cultures were inoculated with $10 \%(\mathrm{v} / \mathrm{v})$ inoculum and were fed with 30 and $50 \mathrm{mM}$ HPA respectively. Fermentation broth spiked with $5 \mathrm{mM}$ of $p$-cresol (predetermined to be the lowest concentration of $p$-cresol causing observable cellular toxicity as shown in Fig. 2), was used with AC to determine whether the presence of AC would mitigate toxicity and enable culture growth. Fermentation broth with $\mathrm{AC}$ but without HPA and without $p$-cresol was also used as experimental control to determine whether there was possible toxicity caused by the AC itself.

From the experimental results, the presence of $\mathrm{AC}$ in the fermentation broth did not cause toxicity to the cells. On the contrary, the expansion ratio of cells with AC but without HPA and without $p$-cresol was higher at 30.7 times as shown in Fig. (4), compared to 10 times when cells were cultured without AC, without HPA and without $p$-cresol as shown in Fig. (2). The expansion ratio of 30.7 times with $\mathrm{AC}$ in Fig. (4) was calculated by dividing the maximum $\mathrm{CFU}$ at $1.87 \times 10^{9}$ with the CFU at inoculation at $6.10 \times 10^{7}$, both normalised on per $\mathrm{ml}$ basis. The expansion ratio without $\mathrm{AC}$ in Fig. (2) was calculated by dividing the maximum OD at 1.50 with the $\mathrm{OD}$ at inoculation at 0.15 , giving an expansion ratio of 10 times. In addition, the specific growth rate of cells with AC but without HPA and without $p$-cresol was observed to be highest at $0.12 / \mathrm{h}$; compared to the growth rate of cells cultured without AC, without HPA and without $p$-cresol at $0.034 \mathrm{~h}$; and the growth rate of cells cultured without $\mathrm{AC}$,

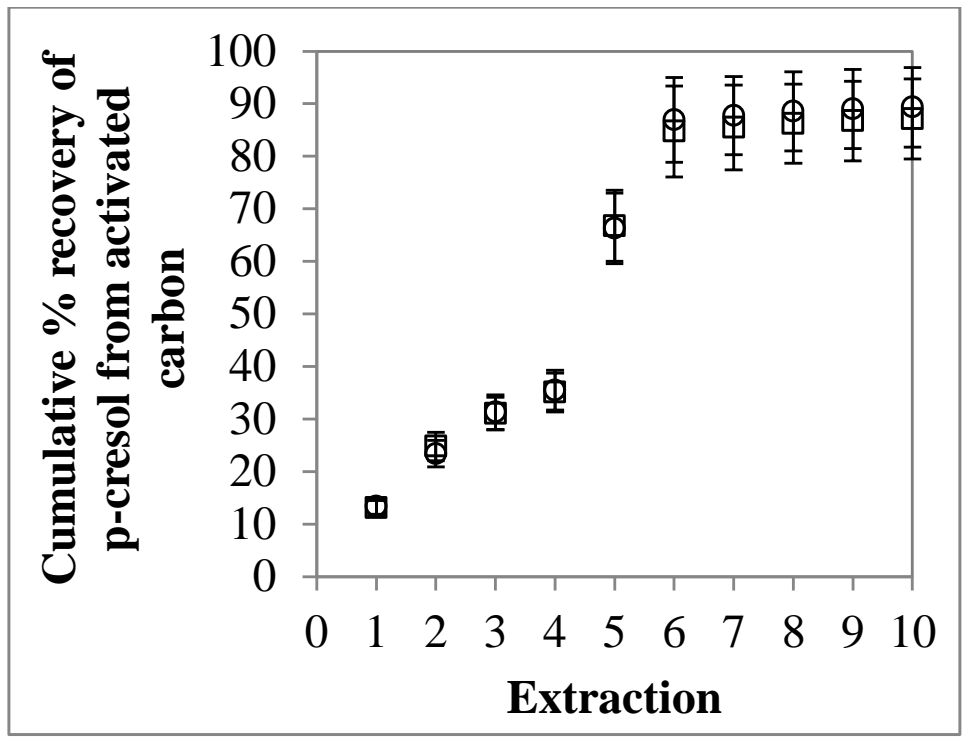

Fig. (3). Ultrasonic-assisted ethanol extraction of $p$-cresol from non-coated AC (O) and Dextran-coated AC ( $\square$ ). 


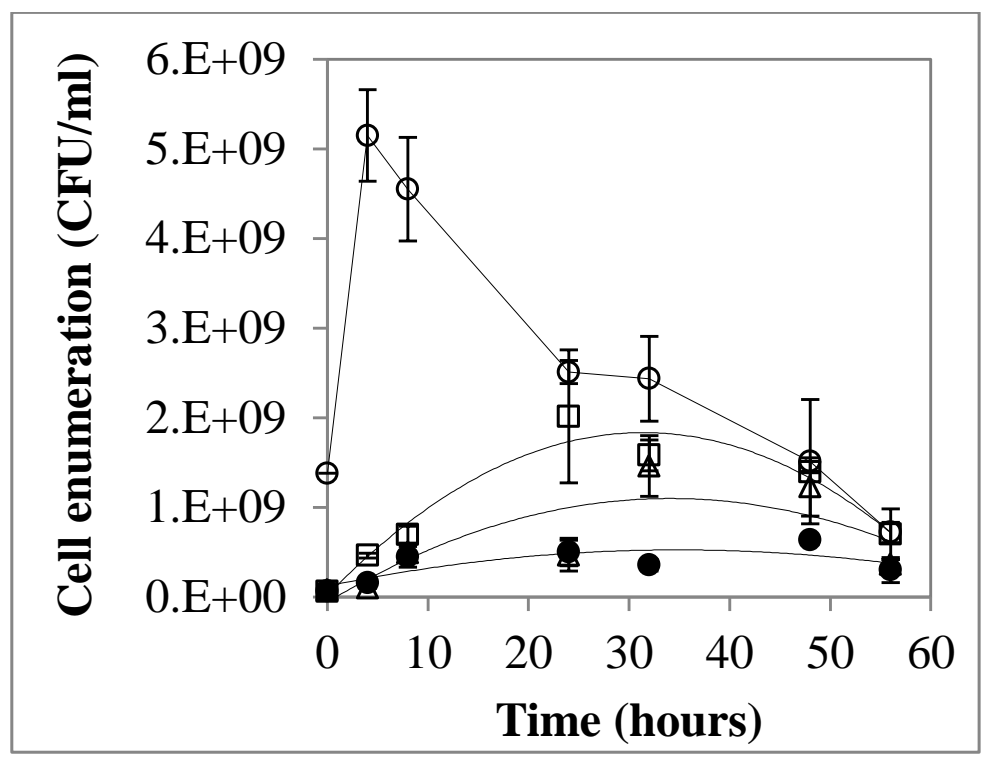

Fig. (4). Growth curves of EM clone at various concentrations of HPA with Dextran-coated AC. 5 mM of $p$-cresol was spiked into the fermentation broth as experimental control without HPA (O). Cells were cultured with various concentrations of HPA at: 0 mM as experimental control $(\square), 30 \mathrm{mM}(\triangle)$ and $50 \mathrm{mM}(\bullet)$.

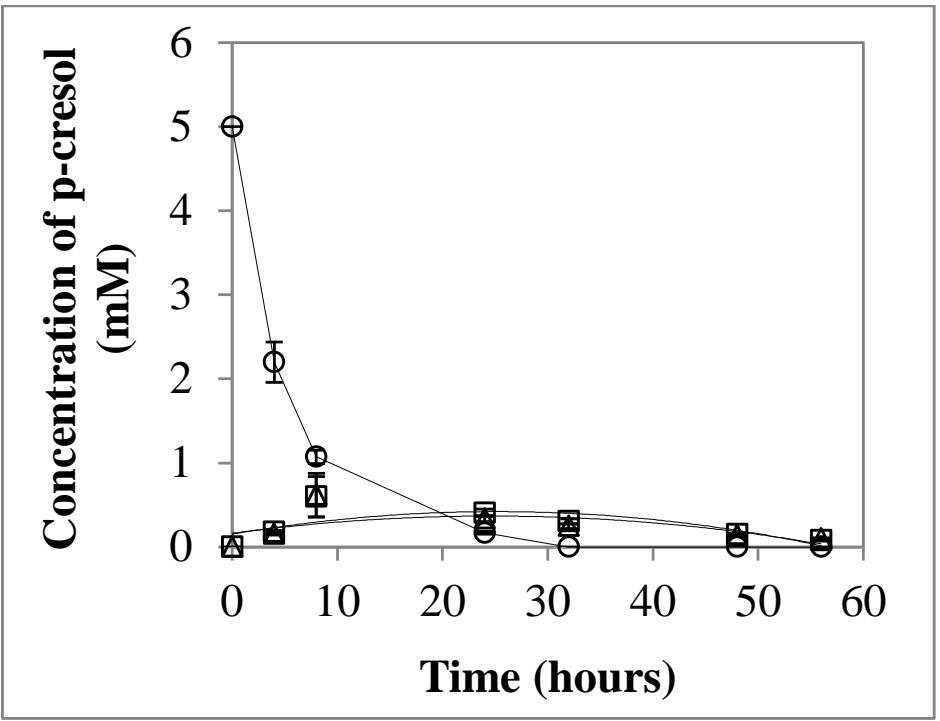

Fig. (5). Production of $p$-cresol by EM clone induced with various concentrations of HPA, and with Dextran-coated AC added to the fermentation broth. $5 \mathrm{mM}$ of $p$-cresol was spiked into the fermentation broth as experimental control without HPA (O). Cells were cultured with various concentrations of HPA at: $30 \mathrm{mM}(\square)$ and $50 \mathrm{mM}(\triangle)$.

without HPA and with $2 \mathrm{mM} p$-cresol at $0.027 / \mathrm{h}$. Toxicity of $p$-cresol was observed to have reduced the specific growth rate of the cells, in agreement with the culture growth curves as shown in Fig. (2).

The presence of AC enabled the cells in the fermentation broth spiked with $5 \mathrm{mM}$ of $p$-cresol to multiply, giving a higher CFU count of $4.79 \times 10^{9} \mathrm{CFU} / \mathrm{ml}$ compared to the initial $1.38 \times 10^{9} \mathrm{CFU} / \mathrm{ml}$ at inoculation as shown in Fig. (4). The concentration of $p$-cresol in the fermentation broth spiked with $5 \mathrm{mM}$ of $p$-cresol was observed to reduce from the initial $5 \mathrm{mM}$ to $0.58 \mathrm{mM}$ by the $4^{\text {th }} \mathrm{h}$, and further decreased to zero by the $32^{\text {nd }} \mathrm{h}$ as shown in Fig. (5). The removal of $p$-cresol from the fermentation broth by the AC was hypothesised to have reduced toxicity, thus enabled cul- ture growth to reach a maximum CFU count of $4.79 \times 10^{9}$ $\mathrm{CFU} / \mathrm{ml}$ at the $4^{\text {th }} \mathrm{h}$ (Fig. 4).

Product removal in-situ fermentation by AC was observed in this study to have mitigated product toxicity and allowed culture growth and continuous production of $p$ cresol as shown in Figs. (4 and 5). $P$-cresol produced by the EM clone was found to be $3605 \mu \mathrm{g}$ from $50 \mathrm{mM}$ of HPA in $20 \mathrm{ml}$ of fermentation broth added with AC. $3396 \mu \mathrm{g}$ of the total of $3605 \mu \mathrm{g}$ of $p$-cresol was recovered from the adsorbent during solvent extraction, while the remaining $209 \mu \mathrm{g}$ of $p$-cresol was detected in the fermentation broth at the time of sampling. On the other hand, $2386 \mu \mathrm{g}$ of $p$-cresol was quantified in the fermentation broth without AC. This showed a 
$51 \%$ increase in $p$-cresol production was possible when AC was used to remove $p$-cresol from the fermentation broth. The prevention of the accumulation of the toxic product in the broth by ISPR allowed the cells to survive and continue production, thus enabling a higher yield to be achieved.

The ISPR strategy demonstrated here in batch fermentation constituted a methodology that could potentially be adapted into a continuous process. As the toxic product was removed from the broth, production could be changed from a product-inhibited to a substrate-limited process, thus enabling higher productivity to be feasible for a product that could otherwise be toxic to the cells. As the AC was produced from renewable materials, and was shown to be recyclable by solvent extraction, the ISPR methodology shown here constituted a production process that was low-cost and sustainable.

\section{CONCLUSIONS}

E. coli cloned with the hpd BCA operon from C. difficile was shown in this study to be able to express $p$ hydroxyphenylacetate decarboxylase and converted the HPA substrate into $p$-cresol under strict anaerobic fermentation. Product toxicity of $p$-cresol at a concentration as low as 5 $\mathrm{mM}$ determined in a separate experiment spiked with $p$ cresol was found to have limited the maximum product concentration at $1 \pm 0.1 \mathrm{mM}$. Product yield was however observed to increase by $51 \%$ when $\mathrm{AC}$ was used to remove $p$ cresol in-situ fermentation. The adsorption capacity for $p$ cresol was determined at $2.6 \pm 0.088 \mathrm{mmol} / \mathrm{g} \mathrm{AC}$. The accumulated $p$-cresol on the $\mathrm{AC}$ was shown to be recoverable by subsequent ultrasonic-assisted ethanol extraction. The decoupling of the solvent extraction process from fermentation via adsorption allowed a solvent with a lower boiling point to be used for product recovery. The ISPR strategy demonstrated here constituted a sustainable production process that could mitigate product inhibition and thus improve product yield.

\section{ABBREVIATIONS}

\begin{tabular}{|c|c|c|}
\hline $\mathrm{AC}$ & $=$ & activated carbon \\
\hline C. difficile & $=$ & Clostridium difficile \\
\hline $\mathrm{CFU}$ & $=$ & colony forming unit \\
\hline $\mathrm{CM}$ & $=$ & $\begin{array}{l}\text { positive clone with chloramphenicol resis- } \\
\text { tance }\end{array}$ \\
\hline E. coli & $=$ & Escherichia coli \\
\hline EM & $=$ & $\begin{array}{l}\text { positive clone with erythromycin resis- } \\
\text { tance }\end{array}$ \\
\hline $\mathrm{GC}$ & $=$ & gas chromatography \\
\hline GRAS & $=$ & Generally Recognised As Safe \\
\hline GRE & $=$ & glycyl radical enzyme \\
\hline HPA & $=$ & $p$-hydroxyphenylacetate \\
\hline Hpd & $=$ & $p$-hydroxyphenylacetate decarboxylase \\
\hline HPLC & $=$ & High Performance Liquid Chromatography \\
\hline ISPR & $=$ & in-situ product recovery \\
\hline
\end{tabular}

MSD $=$ mass spectrometer detector

OD $=$ optical density

TB = Terrific Broth

$\mathrm{v} / \mathrm{v}=$ volume by volume

$\mathrm{w} / \mathrm{v} \quad=$ weight by volume

\section{CONFLICT OF INTERESTS}

The author(s) confirm that this article content has no conflicts of interest.

\section{ACKNOWLEDGEMENTS}

The authors are grateful to Professors N. Minton and K. Winzer of the Clostridium Group, University of Nottingham, for the bacterial cells, the consumables for the cloning work, Dr K. Schwarz for the discussions on the cloning work, Professor Gill Stephens for the discussion on the fermentation work, and the Department of Chemical and Environmental Engineering for the support and consumables for the fermentation, in-situ product recovery, product analysis and quantification work.

\section{REFERENCES}

[1] Yu L, Blaser M, Andrei PI, Pierik AJ, Selmer T. 4hydroxyphenylacetate decarboxylases: properties of a novel subclass of glycyl radical enzyme systems. Biochemistry 2006; 45: 9584-92.

[2] Selmer T, Andrei PI. p-hydroxyphenylacetate decarboxylase from Clostridium difficile. Eur J Biochem 2001; 268: 1363-72.

[3] Deneve C, Janoir C, Poilane I, Fantinato C, Collignon A. New trends in Clostridium difficile virulence and pathogenesis. Int $\mathrm{J}$ Antimicrob Agents 2009; 33(S1): S24-8.

[4] Ozkan P, Sariyar B, Utkur FO, Akman U, Hortacsu A. Metabolic flux analysis of recombinant protein overproduction in Escherichia coli. Biochem Eng J 2005; 22: 167-95.

[5] Hafiz S, Oakley CL. Clostridium difficile: isolation and characteristics. J Med Microbiol 1976; 9: 129-37.

[6] Martins BM, Blaser M, Feliks M, Ullmann GM, Buckel W, Selmer T. Structural basis for a Kolbe-type decarboxylation catalysed by a glycyl radical enzyme. J Am Chem Soc 2011; 133: 14666-74.

[7] Dawson LF, Donahue EH, Cartman ST, et al. The analysis of paracresol production and tolerance in Clostridium difficile 027 and 012 strains. BMC Microbiol 2011; 11: 86.

[8] Khan NS, Mishra IM, Singh RP, Prasad B. Modeling the growth of Corynebacterium glutamicum under product inhibition in Lglutamic acid fermentation. Biochem Eng J 2005; 25: 173-8.

[9] Tian Y, Kasperski A, Sun K, Chen L. Theoretical approach to modelling and analysis of the bioprocess with product inhibition and impulse effect. Biosystems 2011; 104: 77-86.

[10] Malinowski JJ. Two-phase partitioning bioreactors in fermentation technology. Biotechnol Adv 2001; 19(7): 525-38.

[11] Wang Z, Dai Z. Extractive microbial fermentation in cloud point system. Enzyme Microb Technol 2010; 46: 407-18.

[12] Heerema L, Wierckx N, Roelands M, et al. In situ phenol removal from fed-batch fermentations of solvent tolerant Pseudomonas putida S12 by pertraction. Biochem Eng J 2011; 53(3): 245-52.

[13] Trivunac K, Stevanovic S, Mitrovic M. Pertraction of phenol in hollow-fiber membrane contactors. Desalination 2004; 162: 93101.

[14] Sardessai YN, Bhosle S. Industrial potential of organic solvent tolerant bacteria. Biotechnol Prog 2004; 20(3): 655-60.

[15] Yang ST. Bioprocessing-from biotechnology to biorefinery. In: Bioprocessing for Value-Added Products from Renewable Resources Amsterdam: Elsevier 2007; pp. 1-24.

[16] Leon R, Martin M, Vigara J, Vilchez C, Vega JM. Microalgae mediated photoproduction of $\beta$-carotene in aqueous-organic two phase systems. Biomol Eng 2003; 20: 177-82. 
[17] Rodriguez-Martinez MF, Kelessidou N, Law Z, Gardiner J, Stephens G. Effect of solvents on obligately anaerobic bacteria. Anaerobe 2008; 14(1): 55-60.

[18] Yabannavar VM, Wang DIC. Strategies for reducing solvent toxicity in extractive fermentations. Biotechnol Bioeng 1991; 37: 716-22.

[19] Guillot S, Kelly MT, Fenet H, Larroque M. Evaluation of solidphase microextraction as an alternative to the official method for the analysis of organic micro-pollutants in drinking water. $\mathrm{J}$ Chromatogr A 2006; 1101: 46-52.

[20] Zhang W, Ni Y, Sun Z, et al. Biocatalytic synthesis of ethyl (R)-2hydroxy-4-phenylbutyrate with Candida krusei SW2026: a practical process for high enantiopurity and product titer. Process Biochem 2009; 44(11): 1270-5.

[21] Cardoso VM, Solano AGR, Prado MAF, Nunan EdA. Investigtion of fatty acid esters to replace isopropyl myristate in the sterility test for ophthalmic ointments. J Pharm Biomed Anal 2006; 42: 630-4.

[22] Embree HD, Chen T, Payne GF. Oxygenated aromatic compounds from renewable resources: motivation, opportunities, and adsorptive separations. Chem Eng J 2001; 84: 133-47.

[23] Nielsen DR, Amarasiriwardena GS, Prather KLJ. Predicting the adsorption of second generation biofuels by polymeric resins with applications for in situ product recovery (ISPR). Bioresour Technol 2010; 101: 2762-9.

[24] Berge-Lefranc D, Vagner C, Calaf R, et al. In vitro elimination of protein bound uremic toxin $p$-cresol by MFI-type zeolites. Microporous Mesoporous Mater 2012; 153: 288-93.

[25] Hadjar H, Hamdi B, Ania CO. Adsorption of p-cresol on novel diatomite/carbon composites. J Hazand Mater 2011; 188: 304-10.

[26] Anbia M, Ghaffari A. Adsorption of phenolic compounds from aqueous solutions using carbon nanoporous adsorbent coated with polymer. Appl Surf Sci 2009; 255: 9487-92.

[27] Huang J. Treatment of phenol and p-cresol in aqueous solution by adsorption using a carbonylated hypercrosslinked polymeric adsorbent. J Hazand Mater 2009; 168: 1028-34.
[28] Liu FQ, Xia MF, Yao SL, Li AM, Wu HS, Chen JL. Adsorption equilibria and kinetics for phenol and cresol onto polymeric adsorbents: effects of adsorbents/adsorbates structure and interface. J Hazand Mater 2008; 152: 715-20.

[29] Ahmaruzzaman M. Adsorption of phenolic compounds on low-cost adsorbents: a review. Adv Colloid Interface Sci 2008; 143: 48-67.

[30] Singh RK, Kumar S, Kumar S, Kumar A. Development of parthenium based activated carbon and its utilisation for adsorptive removal of $p$-cresol from aqueous solution. J Hazand Mater 2008; 155: 523-35.

[31] Wernert V, Schaf O, Faure V, et al. Adsorption of the uremic toxin $p$-cresol onto hemodialysis membranes and microporous adsorbent zeolite silicalite. J Biotechnol 2006; 123: 164-73.

[32] Ayranci E, Duman O. Adsorption behaviours of some phenolic compounds onto high specific area activated carbon cloth. J Hazand Mater 2005; B124: 125-32.

[33] Jain AK, Bhatnagar S, Bhatnagar A. Methylphenols removal from water by low-cost adsorbents. J Colloid Interface Sci 2002; 251: 39-45.

[34] Li A, Zhang Q, Zhang G, Chen J, Fei Z, Liu F. Adsorption of phenolic compounds from aqueous solutions by a water-compatible hypercrosslinked polymeric adsorbent. Chemosphere 2002; 47: 981-9.

[35] Heap JT, Pennington OJ, Cartman ST, Minton NP. A modular system for Clostridium shuttle plasmids. J Microbiol Methods 2009; 78: 79-85.

[36] Cartman ST, Kelly ML, Heeg D, Heap JT, Minton NP. Precise manipulation of the Clostridium difficile Chromosome reveals a lack of association between the tcdC genotype and toxin production. Appl Environ Microbiol 2012; 78(13): 4683-90.

[37] Oakey RE, Ed. Steroid hormones: A practical approach. Oxford: IRL Press, 1988; p. 278

(C) Ng and Kuek; Licensee Bentham Open.

This is an open access article licensed under the terms of the Creative Commons Attribution Non-Commercial License (http://creativecommons.org/licenses/ by-nc/3.0/) which permits unrestricted, non-commercial use, distribution and reproduction in any medium, provided the work is properly cited. 